\title{
Is there a role of hepatic enzymes in the management of penetrating hepatic injuries?
}

\author{
JR Pallett', A Gibbon, JW Keep \\ From London Trauma Conference 2012 \\ London, UK. 4-7 December 2012
}

\section{Background}

The association of hepatic enzymes and blunt hepatic trauma has been widely researched and a general consensus exists on the role of non-operative management of these injuries.[1] Penetrating liver injuries are less common and subsequently, management of the hemodynamically stable patient with a penetrating liver injury remains a greater challenge.

\section{Methods}

A retrospective cohort study of all penetrating and blunt liver injuries at a Level 1 Major Trauma Centre (King's College Hospital NHS Foundation Trust) was undertaken. Cases were defined by having radiological evidence of liver trauma following injury. Initial aspartate transanimase (AST) levels were documented (normal 10-50 IU/L) along with intervention (non-operative or operative) and outcome.

\section{Results}

35 cases of penetrating trauma (3 gunshot wounds, 32 stabbings) over a 48 month period were identified. ISS mean 14.77 (4-36), Length of Stay (LOS) mean 13.97 days (3-54), age mean $26.25 y r s$ (17-52), $97.14 \%$ male. $28.57 \%(\mathrm{n}=10)$ had abnormally elevated AST levels (51 to $188 \mathrm{IU} / \mathrm{L}$ ) at time of presentation to the ED. Of those with elevated initial AST levels, $70 \%(n=7 / 10)$ had an emergency laparotomy compared with $28 \%(n=7 / 25)$ of cases of penetrating trauma with a normal AST level. Initial raised AST was therefore more likely associated with need for operative management $(\mathrm{p}=0.022)$. Of interest, of the three cases with raised AST without laparotomy, one developed a bile leak requiring CBD stent and another developed a pseudoaneurysm and self-discharged prior to further evaluation. In contrast,

Kings College Hospital, UK
28 cases of blunt trauma over a 29 month period were identified with an ISS mean of 26.32 (4-66), LOS mean 24.27 (1-114), mean age of 33.34yrs (1-58.1). 89\% ( $n=25)$ of these blunt liver injuries had elevated AST levels (69 to $3913 \mathrm{IU} / \mathrm{L}$ ) and only 2 cases proceeded to laparotomy which was for associated injuries and not liver trauma.

\section{Conclusion}

There study suggests that raised (AST) is associated with having a laparotomy rather than conservative management in penetrating hepatic injuries and justifies further research into the diagnostic value of hepatic enzymes in the stable patient with penetrating injury.

\section{Published: 28 May 2013}

\section{Reference}

1. Tan KK, Bang SL, Vijayan A, et al: Hepatic enzymes have a role in the diagnosis of hepatic injury after blunt abdominal trauma. Injury 2009, 40(9):978-83.

doi:10.1186/1757-7241-21-S1-S19

Cite this article as: Pallett et al:: Is there a role of hepatic enzymes in the management of penetrating hepatic injuries? Scandinavian Journal of Trauma, Resuscitation and Emergency Medicine 2013 21(Suppl 1):S19.

Submit your next manuscript to BioMed Central and take full advantage of:

- Convenient online submission

- Thorough peer review

- No space constraints or color figure charges

- Immediate publication on acceptance

- Inclusion in PubMed, CAS, Scopus and Google Scholar

- Research which is freely available for redistribution 